\title{
Fanon Pulls Out a Knife and Cuts Adorno's Throat
}

Willem Schinkel \& Rogier van Reekum

Krisis 41 (2): 76-78.

DOI

10.21827/krisis.41.2.38285

\section{Licence}

This work is licensed under a Creative Commons Attribution 4.0 License International License (CC BY 4.0). (C) 2021 The author(s). 


\section{Fanon Pulls Out a Knife and Cuts Adorno's Throat}

Willem Schinkel \& Rogier van Reekum

$[\mathrm{W}]$ hen the colonized hears a speech about Western culture he pulls out his knife - or at least he makes sure it is within reach. (Fanon 2002 [1961], 46) ${ }^{\mathbf{1}}$

Savages are not better human beings. - One can find in Black students (Negerstudenten) of national economy, in Siamese students at Oxford, and in devoted art-historians and musicologists of petty bourgeois background generally the inclination and readiness to combine the appropriation of what

is new and to be learned with a boundless respect for what is established, validated or recognized. (\$ 32)

\section{1}

It is 1952, a year after Adorno wrote Minima Moralia, an acclaimed culmination of cultural criticism. Fanon takes out a knife and cuts Adorno's throat. Let Martin Jay (1984) ruminate over the motherfucker's picture now: no longer mournfulness, not even (this is important) surprise, just despair.You can just see Adorno think, with his despair-ridden deer-in-headlights gaze, 'but that was only a theoretical model!'

Or so we imagine. We imagine Fanon's knife as a device of invention, as partaking in the invention of human beings that he describes, in 1952, in Peau noire, masques blancs. This invention is the invention of modalities of togetherness that do not yet exist, and the very imagination of invention already constitutes what Harney and Moten have called fugitivity (Harney \& Moten 2013). A mode of being that recognizes, as Adorno does, that there is no escape, but also that there is, at least, at the very least and all the time, fugitivity, lines of flight, invention.

\section{II}

What appears to have hardly been noted thus far is that Fanon, anyhow preoccupied with the role of the knife in Algerian (anti-)colonialism, seems to be riffing off of Nazi poet Hanns Johst: "Wenn ich Kultur höre... entsichere ich meinen Browning." What Fanon establishes seems, at first sight, to be the exact inverse of Johst: the deployment of a fascist trope against fascism itself. But he's deploying it against the fascism long recognized (by Du Bois, Césaire, and many others) as expressed in the fact of the colony as both precursor to and experimental testing ground of the European concentration camp.

And this means it's not quite an inversion. It's an inversion that ends up with an excess, a bycatch. Johst inverted gives something that doesn't only put the knife to fascism's throat, but to Adorno's as well. Like a magical mirror showing more than expected - the ghosts in the room - putting the knife to fascism's throat means putting it to something that, more generally, ruminates about its culture, assesses it over against those Adorno calls savages (Wilden) - by which he means Black people, Asians, non-occidentals generally speaking, perhaps accidentals. This something that shows up as Fanon's bycatch to fascism, this excess that extends the very meaning of fascism, is what can simply be called whiteness. Invisible, until it appears in the reflection of Fanon's blade. 
III

Adorno, we imagine, does not survive Fanon. He does not survive this encounter with blackness that he very well knows (herein lies Adorno's exceptional contribution) to be the epicentre of the double helix of fascism and capitalism. And so he avoids it, being caught up in, and most forcefully and tellingly expressing, an affect we might call 'white pessimism' - but only if you promise to crack a smile, or giggle a little at the very idea, at the very thought that this could be an affect one is caught in.

White pessimism acts as, pretends to be, the last defense against... well, what else: history. Against the return of history, of all those ghosts, of lives expended. Payback time. This pretense acts to hold up, swallow and piteously regurgitate the history of mankind so that our future never arrives and is forever cast as a foreshadowing of man's disillusionment. Caved still. Negative dialectics: something to claim to have arrived at, a claim to history, history now undone - undone only now, it is implied.

The catch, of course, is that the pessimism is fully justified. There is nothing to redeem. We will be stripped of everything we may once have thought was ours, and we lack even a single reason to object. As it was gained, it will be lost. Capital will not endure anything else. So as long as one pretends that all of this would eventually come about, that all of this, however contingent, has been unfolding along some temporal arc, progress now unmasked as doom, one is still masking, still clinging to whiteness and, as such, even if resigned to a stationary posture, still waiting for some contradiction, for help. However, as Jonathan Jackson writes to his brother George, "While we await the precise moment when all of capitalism's victims will indignantly rise to destroy the system, we are being devoured in family lots at the whim of this thing. There will be no super-slave" (Jackson 1990, 10-11). There was never going to be one. Dialectics is how this thing called whiteness entertains itself in the meantime. Or, and this cannot be controversial: dialectics tracks the time it takes the master to abolish himself. A long time.

And while we wait: what if we practice pessimism not as any negative conclusion to what humanity, at one time, might have expected, but as the lived reality of our common existence in invention? The ever-recurring inventiveness that lives from, in, and through the failure of the world. Never getting stuck on words. So let's quickly rush past words, words about how white people don't deserve pessimism. White people, like the rest of us, deserve nothing to begin with. The pessimism that is our existence in common was already right there, plenty already, escaping history, coming with us, returning with us. We were never going anywhere, so what's the wait? Why the posture?

\section{IV}

Martin Jay is right to point out the despair and mournfulness on Adorno's face. But why is Adorno not surprised when Fanon cuts his throat? Don't you know he's been talking to Houria Bouteldja all along?

Adorno's despair, this affect of total capture, emerges as the ultimate realization of capital's avowal of its operations as effacement, as desertification. Is there anything negative here? Anything that is not folded into a logic that claims total capture, but that of course fails to achieve it, fails to preclude invention? Why does Adorno appear to believe capital's confession of total capture, this affirmative admission of guilt? 
Why does he perform it? Why, when it is clear (to him) that capital generates outsides, that there are outsides generative of capital, that capital always already presupposed the not-quite-human subjects (not-quite-subjects) of 'race', never quite enlisted as life but always available as death, as objects for the act of killing? Why, when it is clear that, despite all that, there is and will be fugitivity, invention?

Adorno writes: "Hitler's stupidity was a ruse of reason" (\$ 69). Now, in the fullest loyalty of betrayal, let's paraphrase him. Let's substitute Adorno for Hitler (and is this substitution not the secret summary of Adorno's theoretical program?): Adorno's stupidity was a ruse of reason. Now cut it.

\section{Notes}

1 “[...] lorsqu'un colonisé entend un discours sur le culture occidentale, il sort sa machette ou du moins il s'assure qu'elle est à portée de sa main."

\section{References}

Fanon, Frantz. 1952. Peau noire, masques blancs. Paris: Seuil.

Fanon, Frantz. 2002 [1961]. Les damnés de la terre. Paris: La Découverte.

Jackson, George L. 1990 [1972]. Blood in My Eye. Baltimore, MD: Black Classic Press.

Jay, Martin. 1984. Adorno. Cambridge, MA: Harvard University Press.

Harney, Stefano \& Fred Moten. 2013. The Undercommons: Fugitive Planning \& Black Study. Wivenhoe: Minor Compositions.

\section{Biography}

Rogier van Reekum is an assistant professor at the department of Public Administration and Sociology of Erasmus University Rotterdam. His work focuses on the politics of migration and knowledge controversies. Rogier has published on border visuality, nationalism, place making, citizenship \& migration politics, immigration policy and education.

Willem Schinkel is professor of social theory at Erasmus University Rotterdam. 